\title{
The Potential Global Distribution of Sirex juvencus (Hymenoptera: Siricidae) under Near Current and Future Climatic Conditions as Predicted by the Maximum Entropy Model
}

\author{
Tai Gao $\mathbb{D}$ and Juan Shi *
}

Citation: Gao, T.; Shi, J. The Potential Global Distribution of Sirex juvencus (Hymenoptera: Siricidae) under Near Current and Future Climatic Conditions as Predicted by the Maximum Entropy Model. Insects 2021, 12, 222. https://doi.org/ $10.3390 /$ insects 12030222

Academic Editor: Michael E. Dillon

Received: 26 January 2021

Accepted: 2 March 2021

Published: 5 March 2021

Publisher's Note: MDPI stays neutral with regard to jurisdictional claims in published maps and institutional affiliations.

Copyright: (c) 2021 by the authors. Licensee MDPI, Basel, Switzerland. This article is an open access article distributed under the terms and conditions of the Creative Commons Attribution (CC BY) license (https:// creativecommons.org/licenses/by/ $4.0 /)$.
Sino-France Joint Laboratory for Invasive Forest Pests in Eurasia, Beijing Forestry University, Beijing 100083, China; gaotai36@outlook.com

* Correspondence: shi_juan@263.net; Tel.: +86-130-1183-3628; Fax: +86-10-6233-6423

Simple Summary: The difference in the potential distribution of Sirex juvencus (Hymenoptera: Siricidae) under current and future climatic conditions is dependent on environmental factors such as temperature and precipitation, which can affect survival. In this study, we investigated the impact of climate change on the distribution and spread of an invasive insect pest species of forestry, $S$. juvencus. This wood wasp drills holes on a tree trunk or branch with ovipositor and then deposits eggs inside the hole, along with a wood-rotting fungus which helps its larva to digest the host plant. We analyzed the current distribution data from Asia, Europe, and North America with the maximum entropy model and revealed that the species might increase its distribution area as ambient temperature increases and precipitation (moisture) declines. There is also evidence to show that the species will spread more in moderately suitable areas. The species can also co-infest hosts along with other Sirex species of wood wasp, making its potential impact highly significant.

Abstract: Wood wasp species in the genus Sirex are known pests of forestry. They cause significant economic losses due to their impacts on plant health and wood quality. S. juvencus (Hymenoptera: Siricidae), widely distributed in Asia, Europe, and North America, is known to negatively impact forestry, infesting Picea, Pinus, Larix, Abies, Cupressus, and Pseudotsuga species. This pest destroys plants by depositing eggs, mucus, and its obligate mutualistic fungus, Amylostereum areolatum. Its obligate mutualistic fungus is to provide nutrition for $S$. juvencus larva. Despite its extensive distribution range, little is known about which environmental variables significantly impact current and future distribution patterns of $S$. juvencus for pest control and monitoring. Here we used the maximum entropy model in conjunction with occurrence points of $S$. juvencus and environmental variables to predict the current and future global potential distribution of S. juvencus. We used the jackknife method and Pearson's correlation analysis to select the environmental variables that influence the geographic distribution of $S$. juvencus, which resulted in the inclusion of the monthly average maximum temperature in February, the max temperature of warmest month, monthly average minimum temperature in July, monthly total precipitation in June, precipitation of the driest month, monthly total precipitation in September, and the temperature annual range. Temperature and precipitation are mainly likely to drive the distribution enabled by its obligate mutualistic fungus and the potential to co-infect with other Sirex species. The high temperature and low humidity influence $S$. juvencus eggs and larvae directly and indirectly via fungus-growth, which enables the larvae to survive. Furthermore, $S$. juvencus may increase its distribution to moderately suitable areas due to competition or dependency on other Sirex species during the infestation. Under the future climatic conditions, the highly suitable area increased by $32.79 \%$, while the moderately suitable area, low suitable area, and unsuitable area increased by $28.14 \%, 3.30 \%$, and $2.15 \%$. Under climate changes, S. juvencus may spread in previously unsuitable areas rapidly.

Keywords: Sirex wood wasp; MaxEnt; potentially suitable area; climate change; CMIP6; co-infestation; pest control 


\section{Introduction}

Sirex juvencus (Hymenoptera: Siricidae) is a widely distributed wood-boring wasp species in Canada, the U.S., Mongolia, China, Japan, Europe, and some west Asian countries [1-19]. As with other Sirex species, it is an important pest of conifers with high ecological and commercial value [20]. The Sirex species' life cycle is about one year, but S. juvencus can be up to two years. For males and females, the emergence period of Sirex species tends to be close, even though the males emerge earlier. By using the ovipositor, the female pierces the host plant, drilling through the phloem to the xylem, with multiple tunnels in the xylem during oviposition. During oviposition, the female $S$. juvencus not only deposits eggs into the tunnel, but also injects the obligate mutualistic fungus, Amylostereum areolatum [21], and the mucus into other tunnels. The mucus contains a phytotoxin that promotes the growth of the fungus. Its obligate mutualistic fungus can weaken the host plant's immune system and destroy the cellulose and lignin [22]. Researchers have shown that neither mucus nor its obligate mutualistic fungus can directly cause tree death alone. It is only the combination of mucus and its obligate mutualistic fungus that can cause the tree to be weakened or die $[23,24]$. The mucus and its obligate mutualistic fungus have severe negative impacts on wood quality and ultimately reduce the wood's commercial value. Once a tree is infested, it can never recover again; this is a substantial economic loss [25,26].

Compared to other Sirex species, S. juvencus has a longer lifecycle and shows a preference for weakened or dying trees that other Sirex species have infested. Still, it can also infest living spruce [26]. This is a unique feature of this particular species. Furthermore, its distribution is known to be in Asia, Europe, and North America, but its potential to spread to other regions has not been investigated before. Considering the impacts of climate change and prevalence of $S$. juvencus, it is essential to ascertain what effects will result from changes in environmental factors and how these could influence the spread of invasive alien species (IAS), as well as to assist in the development of a monitoring and evaluation strategy $[27,28]$.

Under global climate change, previously unsuitable habitats may become more habitable [29]. The model used in most of these studies uses data on climatic variables in the current occurrence areas and some of the species' characteristics to predict possible suitable habitats under various climate scenarios. Maximum entropy theory is one such model and predicts species' potential distribution area using occurrence points and environmental variables [30-33]. And the maximum entropy model has been applied in various studies predicting habitat suitability for plants, animals, and fungi [34-37], especially in invasion biology studies. The maximum entropy model is highly advantageous above other models due to its faster operational capability, simplicity of operation, stable calculation results, and high accuracy [38]. The maximum entropy model is ideal for studying the distribution patterns of Sirex wood wasps since they occur in areas that are poorly accessible, making it challenging to collect occurrence data due to their extensive habitat ranges.

This study aimed to predict the potential global geographic distribution of $S$. juvencus and the environmental variables driving this under near current and future climate scenarios using the maximum entropy model and the Coupled Model Intercomparison Project Phase 6 (CMIP6) data. The environmental variables used in this study are download from the WorldClim v2.1 (https: / / www.worldclim.org/) (accessed on 4 March 2021). We used the environmental variables of the future climate condition, the periods of the 21st century, under four shared socio-economic pathways (SSPs), including ssp126, ssp245, ssp370, and ssp585. We chose the medium-resolution National (Beijing) Climate Center Climate System Model (BCC-CSM2-MR), as the global climate model (GCM), to predict the potential distribution areas of $S$. juvencus under future climate conditions. We attempt to understand the factors that could drive the species to prefer weakened or dying trees to infest and explain its current global distribution relative to other Sirex species. 


\section{Materials and Methods}

\subsection{The Source of Occurrence Points}

The occurrence data of $S$. juvencus were obtained from the following sources: (1) the collection records of $S$. juvencus specimens deposited in Beijing Key Laboratory for Forest Pests Control (Beijing Forestry University, BFU, Beijing, China), Unité de Recherche de Zoologie Forestière d'Orléans (l'Institut National de Recherche pour l'Agriculture, l'Alimentation et l'Environnement, INRAE, Orléans, France), National Zoological Museum of China (Chinese Academy of Science, CAS, Beijing, China), and Research Institute of Forest Ecology, Environment, and Protection (Chinese Academy of Forestry, CAF, Beijing, China); (2) published references related to S. juvencus [1-19]; (3) the pest's distribution databases including GBIF (https: / / www.gbif.org/) (accessed on 4 March 2021), CABI (https:/ / www.cabi.org/) (accessed on 4 March 2021), INPN (https://inpn.mnhn.fr/accueil/index) (accessed on 4 March 2021), NBN Atlas (https: / / nbnatlas.org/) (accessed on 4 March 2021), and PESI (http:/ / www.eu-nomen.eu/portal/index.php) (accessed on 4 March 2021); (4) the observational data collected from 2016 to 2020, with which we investigated 83 historical and potential occurrence points in China and Europe. Finally, we have collected 651 occurrence points of $S$. juvencus from the above sources, distributed in Asia, Europe, and North America.

\subsection{The Selection of Occurrence Points}

We used Google Earth 7.1 (Google Inc., Mountain View, CA, USA) to check the latitude and longitude of the collected occurrence points. To eliminate the influence of large spatial correlation and over-fitting simulation, we used the buffer analysis to filter the occurrence points that were too close. The spatial resolution of environmental variables used in this study was 2.5 arc-minutes, covering about $21 \mathrm{~km}^{2}$, with the buffer zone's radius set to $2.5 \mathrm{~km}$. Only one occurrence point was retained when the distance between the occurrence points was less than $5.0 \mathrm{~km}$ [39].

\subsection{Environmental Variables}

Insect species' distribution patterns are influenced by various environmental variables [40]. The environmental variables used in this study can be seen in Table 1 . We used the ArcMap software v10.2 (Environmental Systems Research Institute Inc., Redlands, CA, USA) to convert the environment variables from *.tif format to *.asc format, in preparation for use in the MaxEnt software 3.4.1 (Princeton University, Princeton, NJ, USA). The coordinate system was set to WGS 1984. Since too many variables can increase the ecological space dimension, which can then affect the predicted performance and accuracy of the maximum entropy model, we used the jackknife analysis in the MaxEnt software to obtain the percent contribution of each environmental variable [41-43]. We extracted the environmental variables' climate information of all occurrence points using the ArcMap software. We used Pearson's correlation analysis to calculate the relationship between the climatic and environmental variables using the SPSS software v20.0.0 (International Business Machines Corporation, Armonk, NY, USA) [44]. 
Table 1. Environmental variables used in predicting the potential distribution of S. juvencus.

\begin{tabular}{ccc}
\hline Climate Variables & Code & Unit \\
\hline Annual mean temperature & bio1 & ${ }^{\circ} \mathrm{C}$ \\
Mean diurnal range & bio2 & ${ }^{\circ} \mathrm{C}$ \\
Isothermality & bio3 & ${ }^{\%}$ \\
Temperature seasonality & bio4 & - \\
Max temperature of warmest month & bio5 & ${ }^{\circ} \mathrm{C}$ \\
Min temperature of coldest month & bio6 & ${ }^{\circ} \mathrm{C}$ \\
Temperature annual range & bio7 & ${ }^{\circ} \mathrm{C}$ \\
Mean temperature of wettest quarter & bio8 & ${ }^{\circ} \mathrm{C}$ \\
Mean temperature of driest quarter & bio9 & ${ }^{\circ} \mathrm{C}$ \\
Mean temperature of warmest quarter & bio10 & ${ }^{\circ} \mathrm{C}$ \\
Mean temperature of coldest quarter & bio11 & ${ }^{\circ} \mathrm{C}$ \\
Annual precipitation & bio12 & $\mathrm{mm}$ \\
Precipitation of wettest month & bio13 & $\mathrm{mm}$ \\
Precipitation of driest month & bio14 & $\mathrm{mm}$ \\
Precipitation seasonality & bio15 & - \\
Precipitation of wettest quarter & bio16 & $\mathrm{mm}$ \\
Precipitation of driest quarter & bio17 & $\mathrm{mm}$ \\
Precipitation of warmest quarter & bio18 & $\mathrm{mm}$ \\
Precipitation of coldest quarter & bio19 & $\mathrm{mm}$ \\
Monthly average minimum temperature & tmin1-tmin12 & ${ }^{\circ} \mathrm{C}$ \\
Monthly average maximum temperature & tmax1-tmax12 & ${ }^{\circ} \mathrm{C}$ \\
Monthly total precipitation & prec1-prec12 & $\mathrm{mm}$ \\
\hline
\end{tabular}

\subsection{Maximum Entropy Model Optimization}

The maximum entropy model parameters set in this study were as follows: create response curves and jackknife to measure variable importance; cloglog output mode [33]; output file format as *asc format. For predicting the potentially suitable distribution area under future climate conditions, the filenames of future climate variable data were set to correspond to the near current climate variables and loaded into "Projection layers directory/file".

The following parameters were also used in the model analysis. We used random seed, which is similar to bootstrapping, where each run will use a different random seed. The random test percentage was set to 25 , which means that $75 \%$ of the occurrence points are randomly selected as the training set, and the remaining $25 \%$ are used as the test set. We used the ArcMap software, DIVA-GIS software v7.5.0 (https://www.diva-gis.org/) (accessed on 4 March 2021), and R software v4.0.3 (https:/ / www.r-project.org/) (accessed on 4 March 2021) to calculate the regularization multiplier (RM). The R packages ENMeval, dismo, dotCall64, fields, grid, knitr, maps, maptools, raster, rgeos, sp, spam, and spThin were used to calculate the RM and feature classes (FC). The RM was set to $0.5,1.0,1.5$, 2.0, 2.5, 3.0, 3.5, and 4.0. The FC included linear $(\mathrm{L})$, quadratic $(\mathrm{Q})$, hinge $(\mathrm{H})$, product $(\mathrm{P})$, and threshold $(\mathrm{T})$. The ENMeval package was used to calculate the corrected Akaike information criterion correction value (AICc value) under different parameters. The AICc value was used to estimate the maximum entropy model's complexity, with the smallest AICc value corresponding to the FC combination and preferred RM [45]. We tested eight different FC combinations, including L, LQ, LQP, QHP, LQH, LQHP, QHPT, and LQHPT [32,46,47]. The checkerboard2 method was used to calculate the AICc value. The model was run 20 times under the same setting to further reduce the randomness of predicted results, with the final result presented as the replicates' average [48].

\subsection{Classification of Potentially Suitable Areas}

The *asc format file resulting from $20 \times$ replication of the maximum entropy model was converted to a raster by ArcMap. The worldwide distribution range of $S$. juvencus was analyzed using ArcMap. This study used the lowest presence threshold (LPT) to define the suitable distribution area and unsuitable distribution area [49]. The contents 
of the potential distribution areas were divided into four categories including unsuitable areas (0-LPT), low suitable areas (LPT-0.4), moderately suitable areas (0.4-0.6), and highly suitable areas (0.6-1.0).

\subsection{The Predictive Accuracy of the Maximum Entropy Model}

The area under the receiver operating characteristic (ROC) curve (AUC), the AUC value, is widely used to estimate the predictive accuracy of the maximum entropy model [50-52]. The following criteria are used to determine if the predicted accuracy has no predictive ability or a high predictive ability: AUC value range from $0.5 \leq$ to $\leq 1$; the output showing $0.5 \leq \mathrm{AUC} \leq 0.6$ is considered no predictive ability; $0.6<\mathrm{AUC} \leq 0.7$ is a poor predictive ability; $0.7<$ AUC $\leq 0.8$ is a general predictive ability; $0.8<$ AUC $\leq 0.9$ is a moderate predictive ability; $0.9<$ AUC $\leq 1.0$ is a high predictive ability. To eliminate the possible deviations of the AUC value, we used the AUC value of the partial-area ROC (P-ROC AUC) to estimate the predictive accuracy of the maximum entropy model. We used a 5\% error rate $(\mathrm{E}=0.05)$ to calculate the $\mathrm{AUC}$ ratios, $\mathrm{AUC}$ ratio $=\mathrm{AUC}_{\mathrm{E}} / \mathrm{AUC}_{0.5}$, by using the Niche Analyst software v3.0 (http:/ / nichea.sourceforge.net/) (Calculate AUC value of partial-area ROC approaches). The AUC ratio $>1$ indicated that the model has a high credibility [53]. Moreover, we used a minimum training presence omission rate (ORmtp), 0 as expected value, and 10 percentile training presence omission rates (OR10), 0.1 as the expected value, to verify whether the model was overfitting $[30,49,54]$. When the model has a higher AUC value and a lower omission rate, it means it has a high predictive ability.

\section{Results}

\subsection{The Major Parameters of the Maximum Entropy Model}

We used buffer analysis to all collected 651 occurrence points and finally got 270 occurrence points of the S. juvencus, distributed in Asia, Europe, and North America, for the maximum entropy model. By using the jackknife analysis and Pearson's correlation analysis to select bioclimatic/environmental variables, the results of selected environmental variables are shown in Table 2. The FC combination of the maximum entropy model in this study was QHP and the RM was 1.5 (Figure 1).

Table 2. Environmental variables used in predicting the potential geographic distribution of S. juvencus.

\begin{tabular}{ccc}
\hline Climate Variables & Unit & Percent Contribution \\
\hline tmax2 & ${ }^{\circ} \mathrm{C}$ & 33.1 \\
prec6 & $\mathrm{mm}$ & 12.9 \\
bio5 & ${ }^{\circ} \mathrm{C}$ & 3.3 \\
bio14 & $\mathrm{mm}$ & 3.1 \\
$\operatorname{tmin7}$ & ${ }^{\circ} \mathrm{C}$ & 2.7 \\
prec9 & $\mathrm{mm}$ & 1.5 \\
bio7 & ${ }^{\circ} \mathrm{C}$ & 1.5 \\
\hline
\end{tabular}

\subsection{The Predictive Accuracy of the Maximum Entropy Model}

Based on the data of 270 occurrence points of S. juvencus and environmental variables, we used the maximum entropy model to predict the worldwide potential distribution area of S. juvencus. The accuracy of the predicted results was estimated using the AUC value, ORmtp, OR10, and AUC ratio under near current climate and future climate extrapolations. The results showed that the AUC and AUC ratio values of 17 climate conditions were all greater than 0.9 and 1.0, respectively. And the ORmtp and OR10 were all close to their expected value, 0 and 0.1 , respectively (Table 3 ). Under near current climate conditions, the mean omission curve on the test data only had a very slight deviation near the predicted omission (Figure 2). The above results indicated that the maximum entropy model's predicted results had a high predictive ability. 


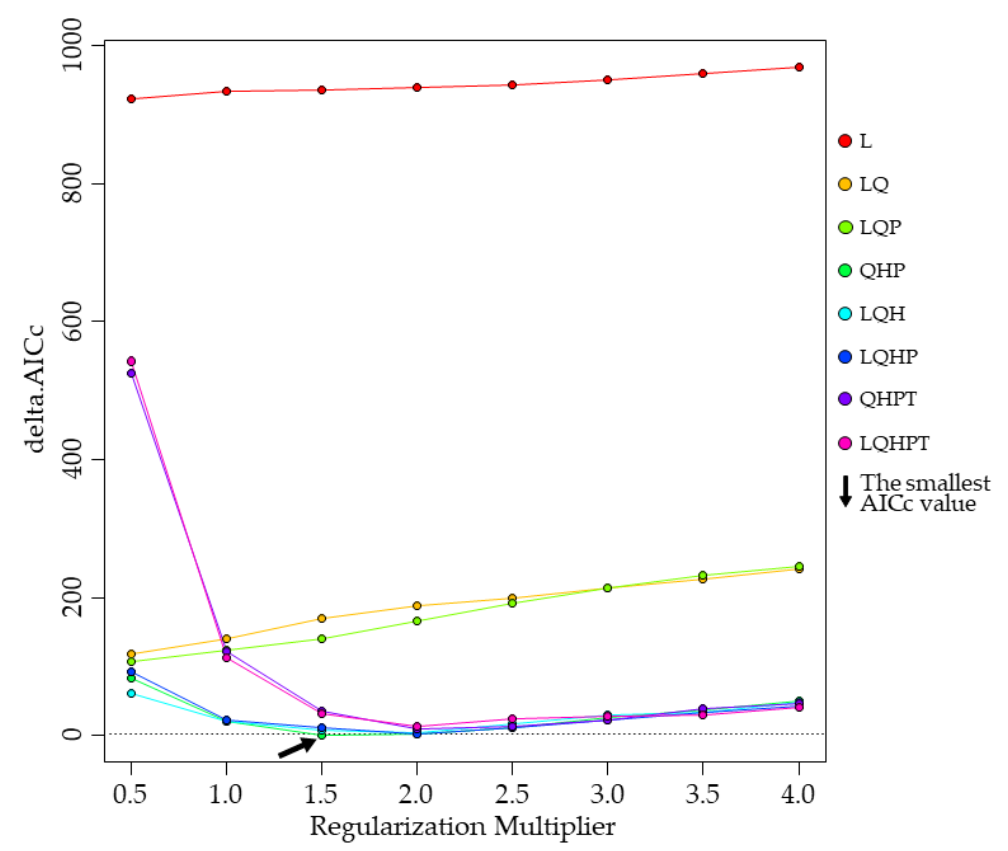

Figure 1. The regularization multiplier and feature classes of S. juvencus in the maximum entropy model.

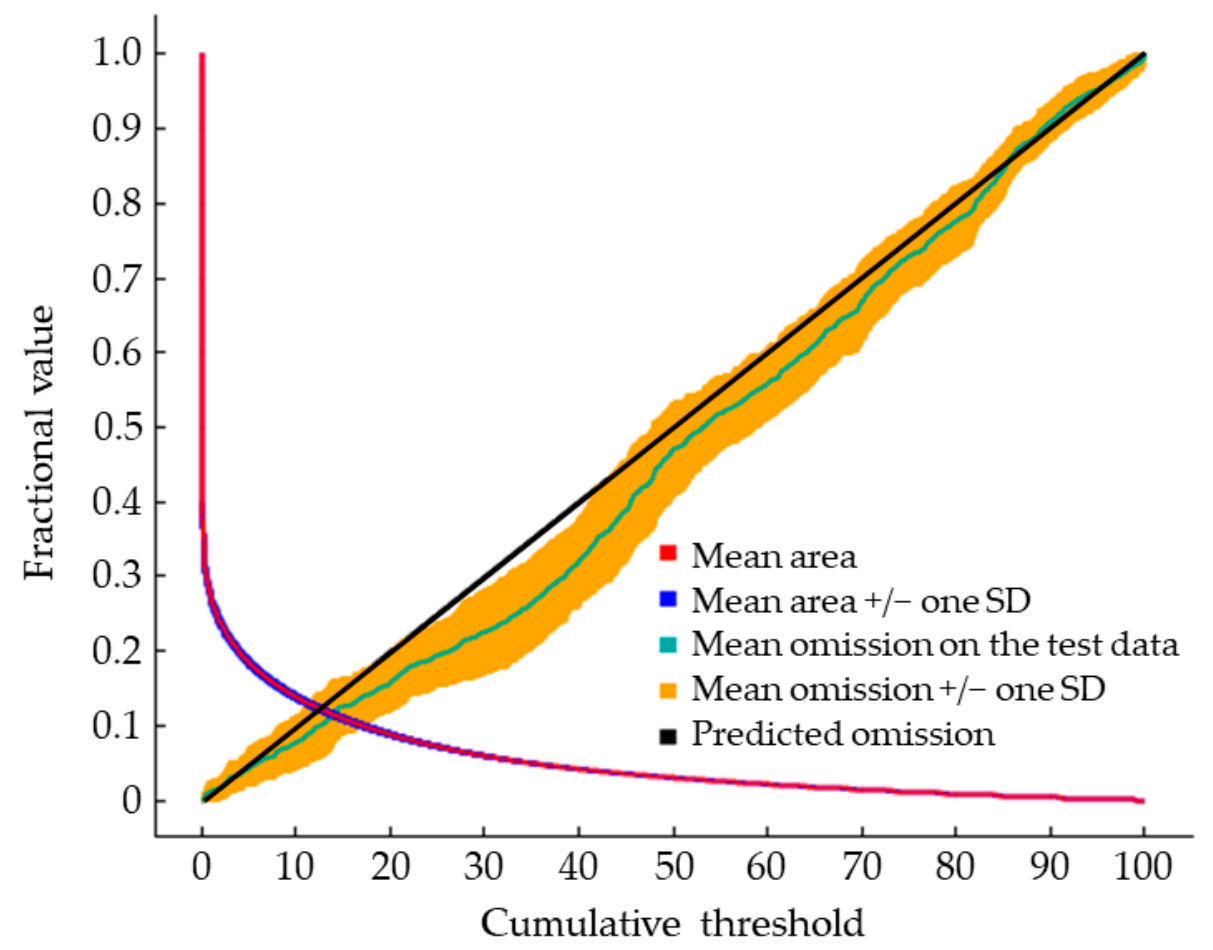

Figure 2. The output of the maximum entropy model's predictive accuracy under near the current climate condition. 
Table 3. The predictive accuracy of the maximum entropy model estimated by AUC, ORmtp, OR10, and AUC ratio.

\begin{tabular}{ccccc}
\hline Climate Scenarios & AUC & ORmtp & OR10 & AUC Ratio \\
\hline Near current & 0.954 & 0.005 & 0.119 & 1.80 \\
$2021-2040$ ssp126 & 0.951 & 0.011 & 0.134 & 1.73 \\
$2041-2060$ ssp126 & 0.959 & 0.002 & 0.124 & 1.72 \\
$2061-2080$ ssp126 & 0.957 & 0.005 & 0.108 & 1.71 \\
$2081-2100$ ssp126 & 0.955 & 0.010 & 0.140 & 1.73 \\
$2021-2040$ ssp245 & 0.953 & 0.006 & 0.137 & 1.74 \\
$2041-2060$ ssp245 & 0.956 & 0.005 & 0.119 & 1.72 \\
$2061-2080$ ssp245 & 0.954 & 0.007 & 0.133 & 1.70 \\
$2081-2100$ ssp245 & 0.957 & 0.003 & 0.101 & 1.69 \\
$2021-2040$ ssp370 & 0.958 & 0.003 & 0.093 & 1.74 \\
$2041-2060$ ssp370 & 0.954 & 0.005 & 0.116 & 1.71 \\
$2061-2080$ ssp370 & 0.956 & 0.005 & 0.117 & 1.64 \\
$2081-2100$ ssp370 & 0.955 & 0.008 & 0.127 & 1.56 \\
$2021-2040$ ssp585 & 0.952 & 0.009 & 0.127 & 1.72 \\
$2041-2060$ ssp585 & 0.956 & 0.005 & 0.131 & 1.67 \\
$2061-2080$ ssp585 & 0.953 & 0.008 & 0.142 & 1.57 \\
$2081-2100$ ssp585 & 0.955 & 0.004 & 0.123 & 1.54 \\
\hline
\end{tabular}

\subsection{The Potential Distribution of S. juvencus under the Near Current Climate Condition}

The 270 occurrence points of S. juvencus were distributed in the Northern Hemisphere: $8^{\circ} \mathrm{W}-53^{\circ} \mathrm{E}, 39^{\circ}-66^{\circ} \mathrm{N}$ in West Eurasia; $85^{\circ}-140^{\circ} \mathrm{E}, 31^{\circ}-52^{\circ} \mathrm{N}$ in East Asia; $56^{\circ}-150^{\circ} \mathrm{W}$, $35^{\circ}-64^{\circ} \mathrm{N}$ in North America (Figure 3a). The potential global distribution of $S$. juvencus under near current and future climatic conditions generated base on minimum training presence Cloglog threshold. The LPT for S. juvencus is 0.0165 . The potentially suitable distribution areas of $S$. juvencus as predicted by the maximum entropy model were divided by LPT into four grades: highly suitable, moderately suitable, low suitable, and unsuitable (Figure $3 \mathrm{~b}$ ). The predicted results showed that the suitable area range is mainly distributed in the Northern Hemisphere under the near current climate condition. The highly suitable area in East and Central Asia is $70^{\circ}-161^{\circ} \mathrm{E}, 26^{\circ}-55^{\circ} \mathrm{N}$; in Europe, West Asia, and North Africa it is $22^{\circ} \mathrm{W}-48^{\circ} \mathrm{E}, 31^{\circ}-71^{\circ} \mathrm{N}$; in North America it is $53^{\circ}-164^{\circ} \mathrm{W}$, $31^{\circ}-62^{\circ} \mathrm{N}$. Areas predicted to be highly suitable areas in Asia included Japan, Russia, China, Mongolia, Myanmar, India, Bhutan, Nepal, Pakistan, Afghanistan, and Kyrgyzstan. With the exception of Moldova, the potentially suitable area of S. juvencus was distributed in all countries in Europe. In Central Asia, S. juvencus was distributed in Armenia, Azerbaijan, Georgia, Turkey, and Iran, while in North Africa, it was distributed in Algeria and Morocco. In North America, S. juvencus was distributed in Canada, the U.S., and Mexico. The moderately suitable areas were mainly distributed around or near highly suitable areas (Figure 3b). In Eurasia, North America, western South America, and eastern Oceania were distributed great-area continuous low suitable areas. In contrast, in some regions, including east-central Africa, western South America, Southern Asia, and northern Oceania, the low suitable areas were sporadically distributed (Figure 3b). Of the total 270 recorded occurrence points, $70.74 \%$ (191) were assigned to highly suitable areas, followed by $19.26 \%$ (52) to low suitable areas, and $10.00 \%$ (27) were assigned to moderately suitable areas (Figure 3). No occurrence points were distributed in the unsuitable areas predicted under near current climate conditions. 

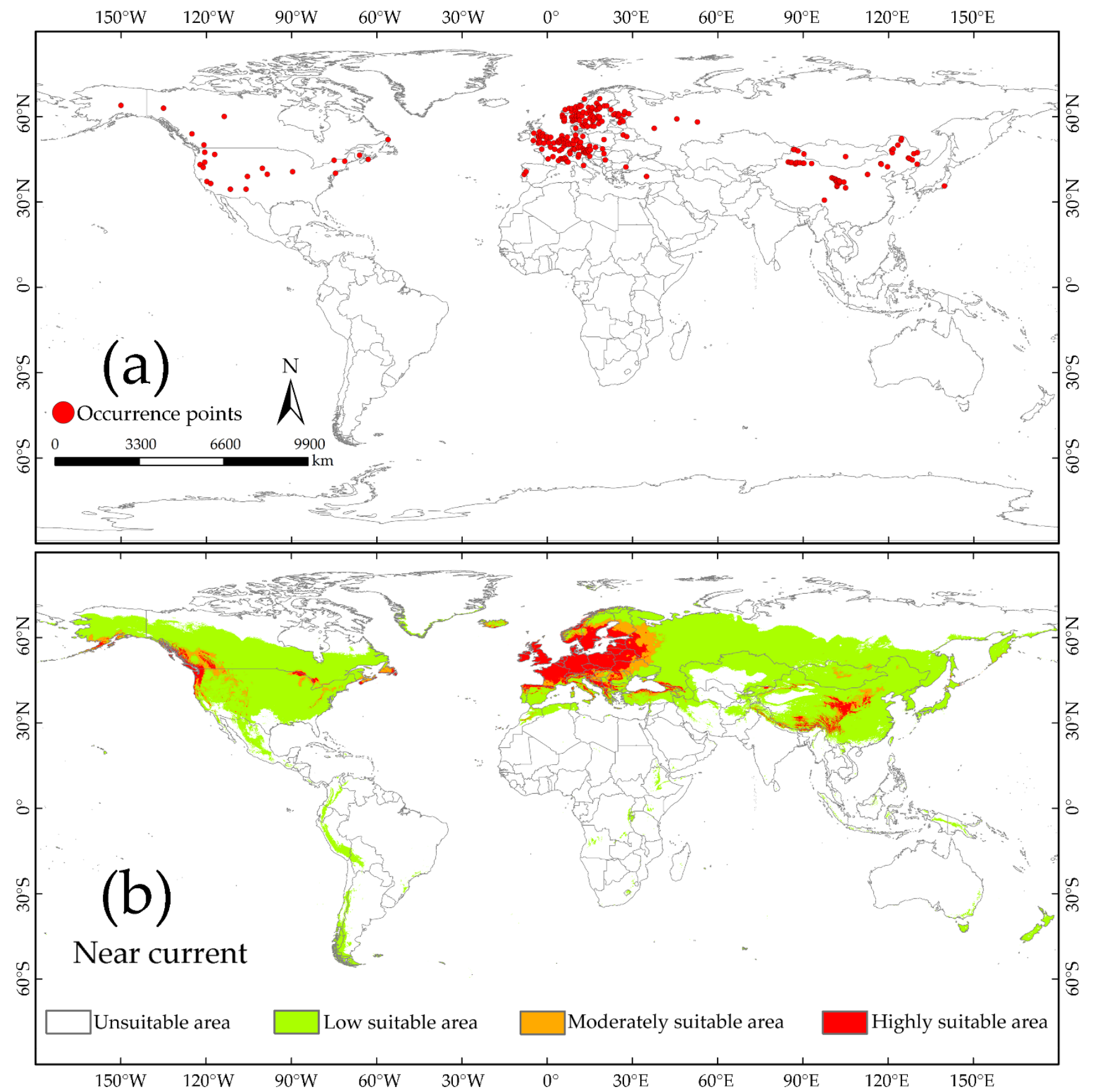

Figure 3. (a) Current occurrence and global distribution of S. juvencus; (b) The predicted area suitability under the near current climate condition. S. juvencus has the potential to occupy over $33.55 \%$ of the land area of the world except for the unsuitable continent, Antarctica, which shows high suitability for the occurrence of S. juvencus.

Globally, there is a potential for the spread of S. juvencus. The predicted highly suitable area for S. juvencus was $0.43 \times 10^{7} \mathrm{~km}^{2}$, accounting for $3.16 \%$ of the total land area; followed by the moderately suitable area covering $0.34 \times 10^{7} \mathrm{~km}^{2}$ and accounting for $2.50 \%$ of the total land area under near current climate conditions (Figures $3 \mathrm{~b}$ and 4 ). A large part of the world remains unsuitable for S. juvencus (Figures $3 \mathrm{~b}$ and 4 ). Highly suitable areas, and moderately suitable areas, increase by between 0.35 and $0.58 \times 10^{7} \mathrm{~km}^{2}$, 0.29 and $0.44 \times 10^{7} \mathrm{~km}^{2}$, respectively, under future climate scenarios (Figure 4). The low suitable areas do not show any significant increase under various future climate conditions (Figure 4). 


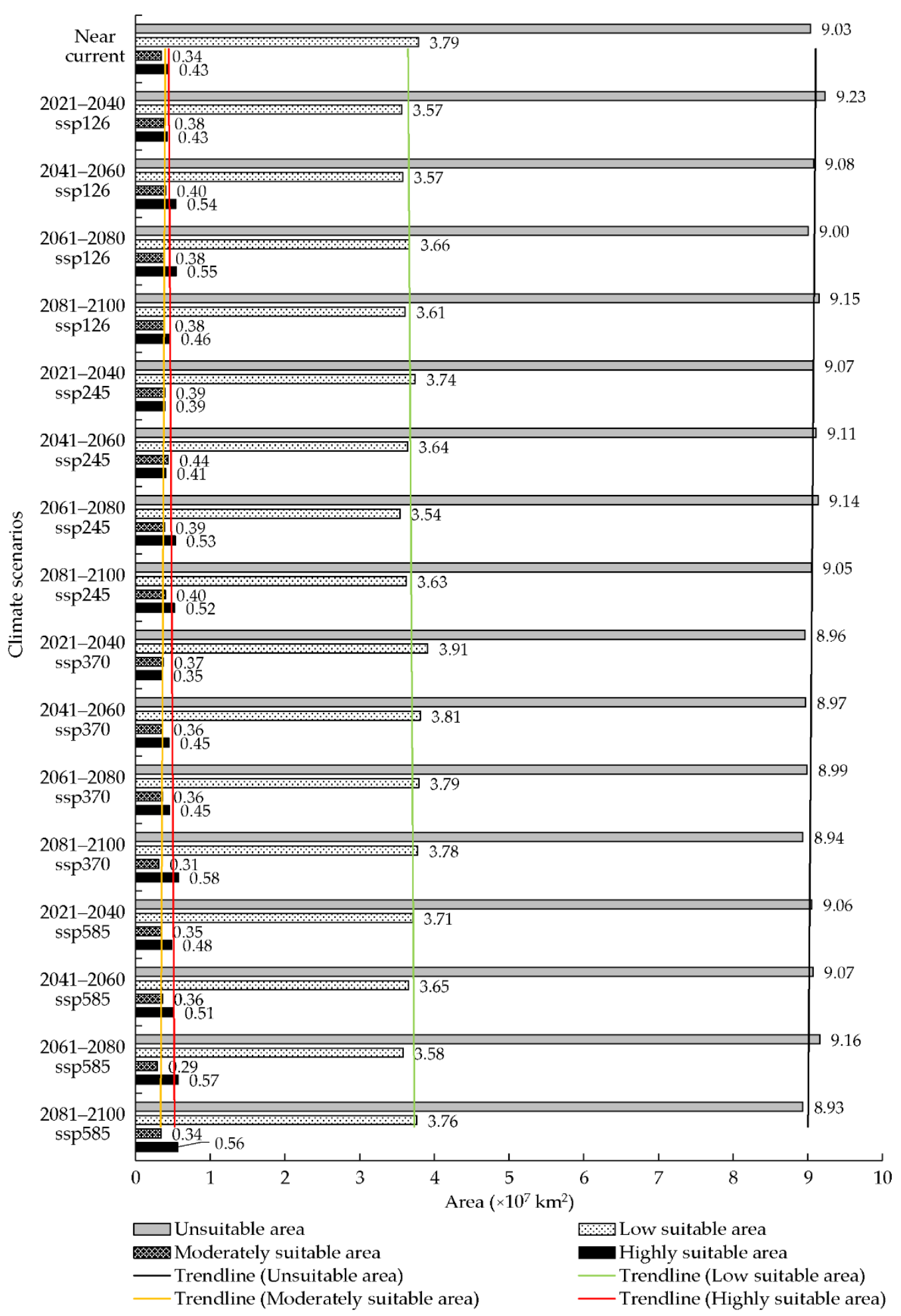

Figure 4. The worldwide suitable areas of S. juvencus under the near current and future climate conditions.

\subsection{The Relationship between the Distribution of S. juvencus and the Environmental Variables}

The jackknife method was used to analyze the importance of the seven environmental variables that strongly impacted the distribution of S. juvencus (Figure 5). The longer the blue bar is, the more influential the variable is to the species distribution, and the shorter the green bar is, the more information the variable has compared to others (Figure 5). Among the seven environmental variables, the two environmental variables that have a greater impact on the distribution of $S$. juvencus were monthly average maximum temperature in 
February (tmax2), max temperature of the warmest month (bio5), and monthly average minimum temperature in July (tmin7) (Figure 5). Besides, the influence of the bio5 and tmin7 are very close. The monthly average maximum temperature in February (tmax2) provided the most information with regard to the distribution of $S$. juvencus, contributed significantly, and gave unique information in predicting area suitability.

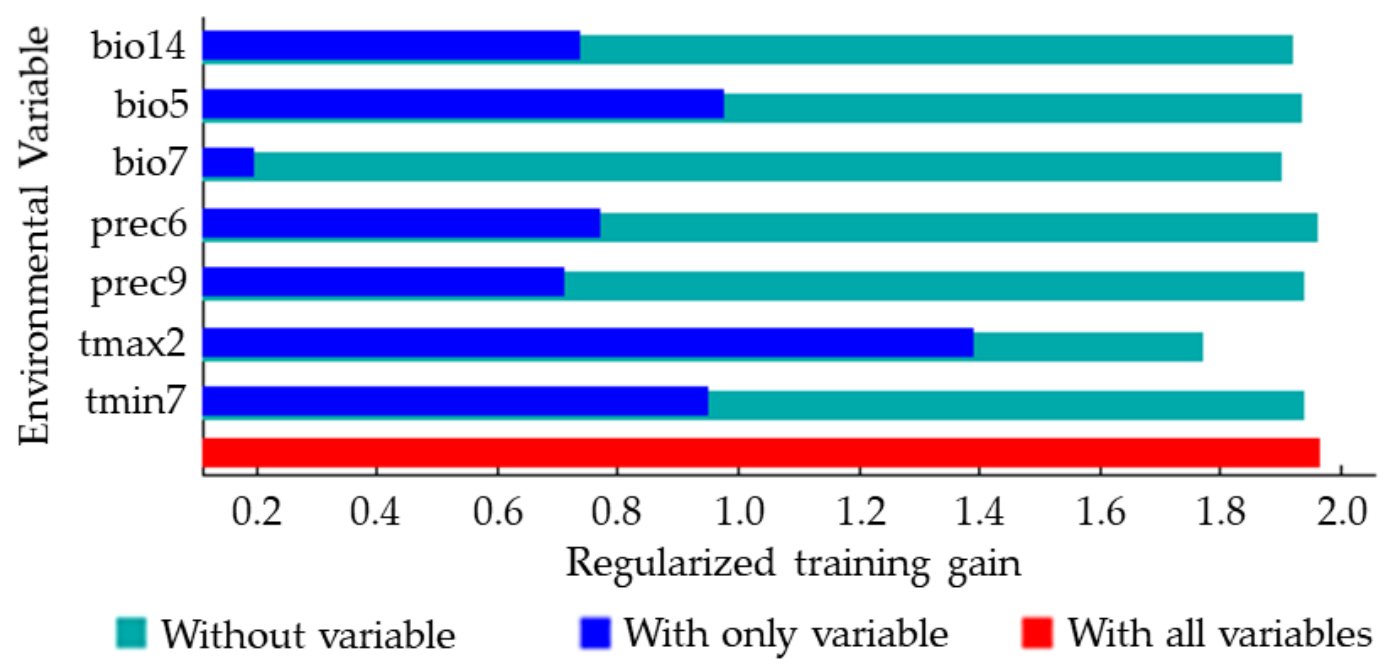

Figure 5. Jackknife analysis result showing the most influential environmental variables predicting potentially suitable distribution areas of $S$. juvencus around the world. The monthly average maximum temperature in February (tmax2) significantly contributed to explaining the suitability of the area for $S$. juvencus. And tmax 2 has the most information that is not present in the other environmental variables.

The response curves between the dominant environmental variables and the distribution probability drawn by the maximum entropy model (Figure 6) reflected the range of environmental variables under different thresholds. In this study, the lowest presence threshold (LPT) was used to divide the range of potentially suitable distribution areas of S. juvencus. The results showed that the suitable temperature under tmax 2 ranged between $-16-20^{\circ} \mathrm{C}$, and the most suitable value was $3{ }^{\circ} \mathrm{C}$. The suitable temperatures in the highly suitable areas ranged between $-4-8{ }^{\circ} \mathrm{C}$. The probability of occurrence increased with increasing temperatures when tma 2 was between $-16-3{ }^{\circ} \mathrm{C}$, and decreased with increasing temperatures when tmax 2 was between $3-20{ }^{\circ} \mathrm{C}$ (Figure 6a). The suitable temperature range for the highly suitable area was predicted to be $17-24^{\circ} \mathrm{C}$ with a suitable bio5 value of $3-36{ }^{\circ} \mathrm{C}$, and the most suitable value was found to be $20^{\circ} \mathrm{C}$ (Figure $6 \mathrm{~b}$ ). When bio5 was between $3-20^{\circ} \mathrm{C}$, the probability of occurrence increased with increasing temperatures, and when bio5 was between $20-36{ }^{\circ} \mathrm{C}$, the probability of occurrence decreased with increasing temperatures. The suitable value for the highly suitable area was predicted to be between $9-14{ }^{\circ} \mathrm{C}$ with a suitable tmin 7 value of $-3-23^{\circ} \mathrm{C}$, and the most suitable value was found to be $12{ }^{\circ} \mathrm{C}$ (Figure $6 \mathrm{c}$ ). The probability of occurrence increases as temperature increases when tmin 7 was between $-3-12{ }^{\circ} \mathrm{C}$ and decreases with increasing temperatures when tmin7 was between $12-23{ }^{\circ} \mathrm{C}$. The suitable value of prec6 for the highly suitable area was between $49-117 \mathrm{~mm}$, with a prec 6 of between $4-520 \mathrm{~mm}$ (Figure $6 \mathrm{~d}$ ). The probability of occurrence increases with increasing precipitation when prec6 ranged between 4-73 $\mathrm{mm}$, and decreases as the precipitation increases when the precipitation was between $73-520 \mathrm{~mm}$. Thus, areas of excess temperature or precipitation could negatively influence the establishment of $S$. juvencus. 

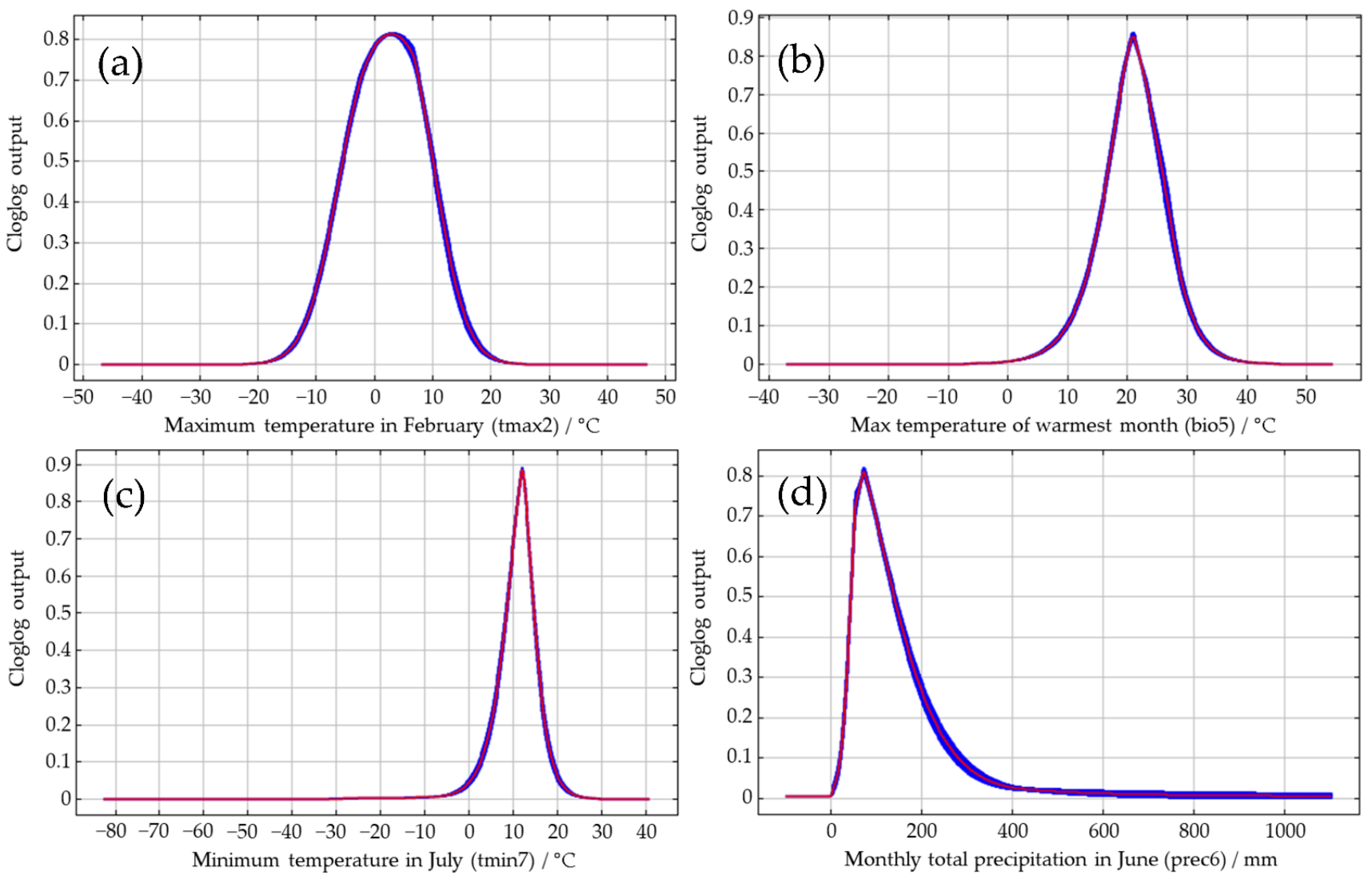

Figure 6. Response curves between the distribution probability of S. juvencus and environmental variables: (a) Maximum temperature in February; (b) Max temperature of warmest month; (c) Minimum temperature in July; (d) Monthly total precipitation in June. Values shown are average over 20 replicate runs: blue margins show \pm SD calculated over 20 replicates.

\subsection{Potential Distribution of S. juvencus under Future Climate Conditions}

Under the future climate conditions, the periods of the 21st century 2021-2040, 2041-2060, 2061-2080, and 2081-2010, under four CMIP6 climate scenarios including ssp126, ssp245, ssp370, and ssp585, showed an increase in predicted area suitability for the distribution of S. juvencus around the world. There is a high potential for S. juvencus to spread into unsuitable areas which are becoming suitable under climate change (Figures 4, 7 and 8). There is an increasing spread of highly suitable areas for the occurrence of $S$. juvencus globally, especially in the northern parts of the world (Figure 7a-d). Moderately suitable and highly suitable areas show an increasing trend under the ssp126 of the future climate conditions in the periods 2061-2080 and 2081-2100 (Figure 7a), during the periods 2041-2060 and 2081-2100 under the ssp245 (Figure 7b), during the periods 2061-2080 and 2081-2100 under the ssp370 (Figure 7c), and during the periods 2041-2060, 2061-2080, and 2081-2100 under the ssp585 (Figure 7d). 


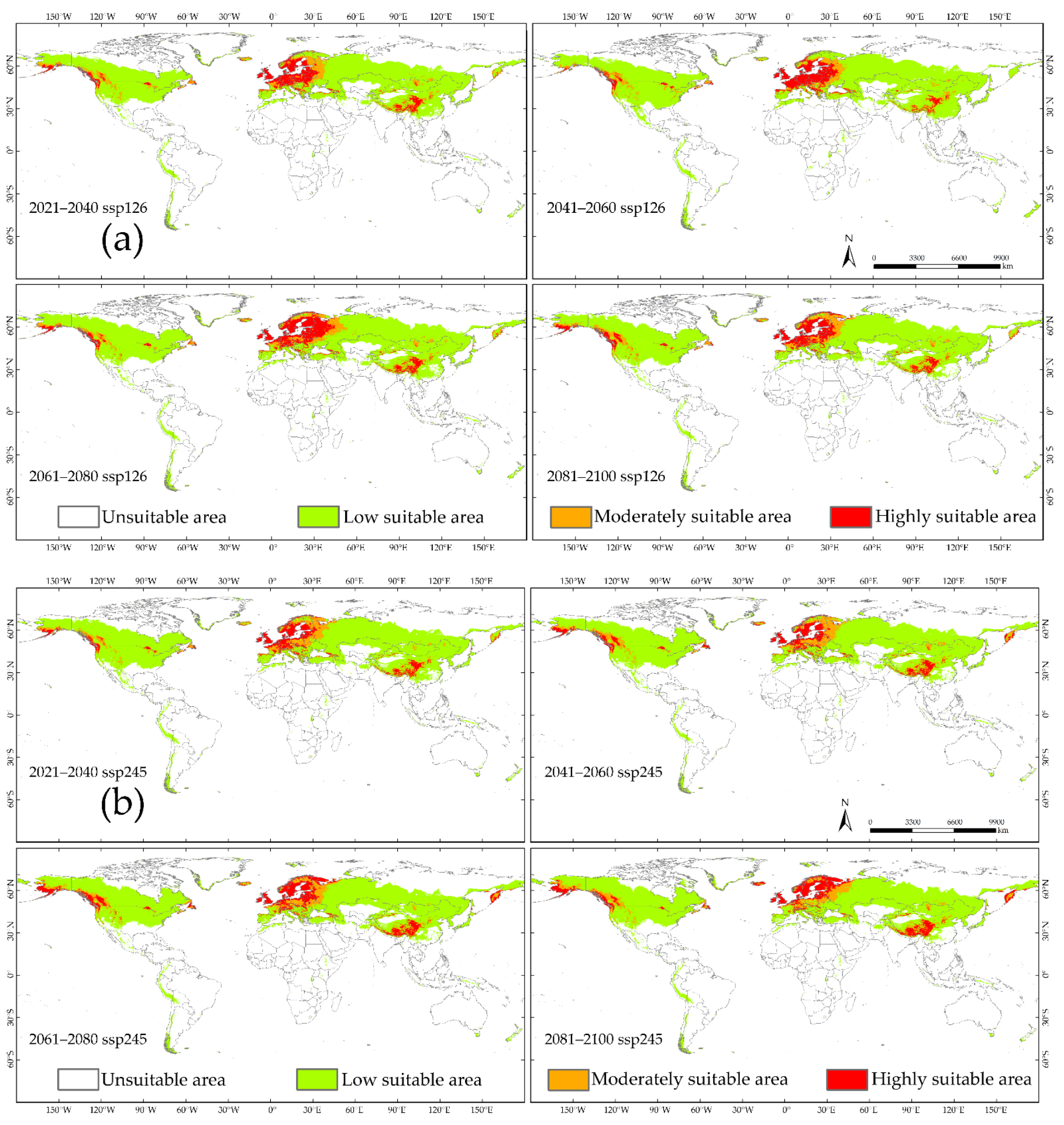

Figure 7. Cont. 


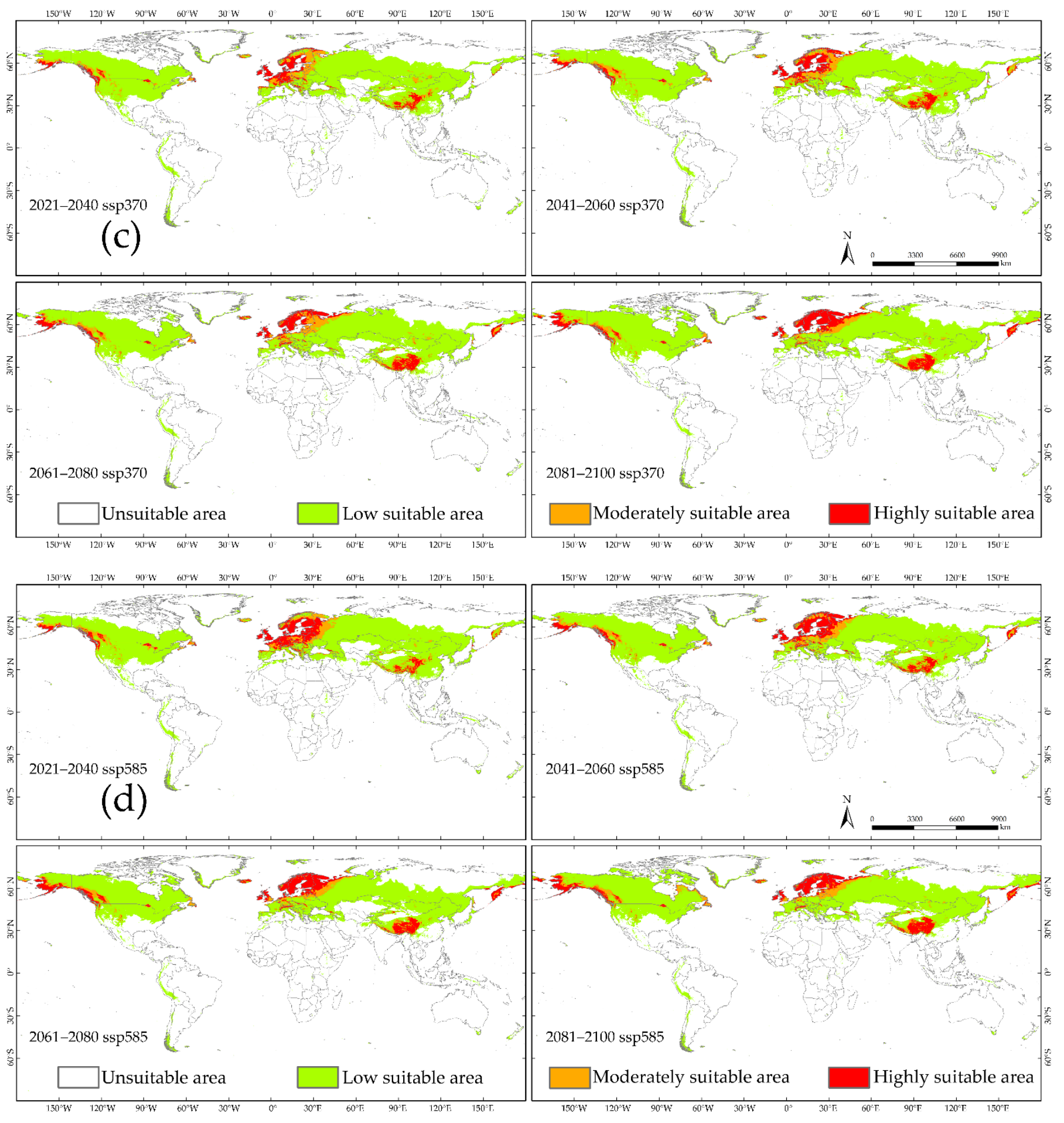

Figure 7. Predicted potential distribution of $S$. juvencus around the world under the future climate conditions during the periods of the 21st century under four CMIP6 climate scenarios and four shared socio-economic pathways: (a) ssp126; (b) ssp245; (c) ssp370; (d) $\operatorname{ssp} 585$. 


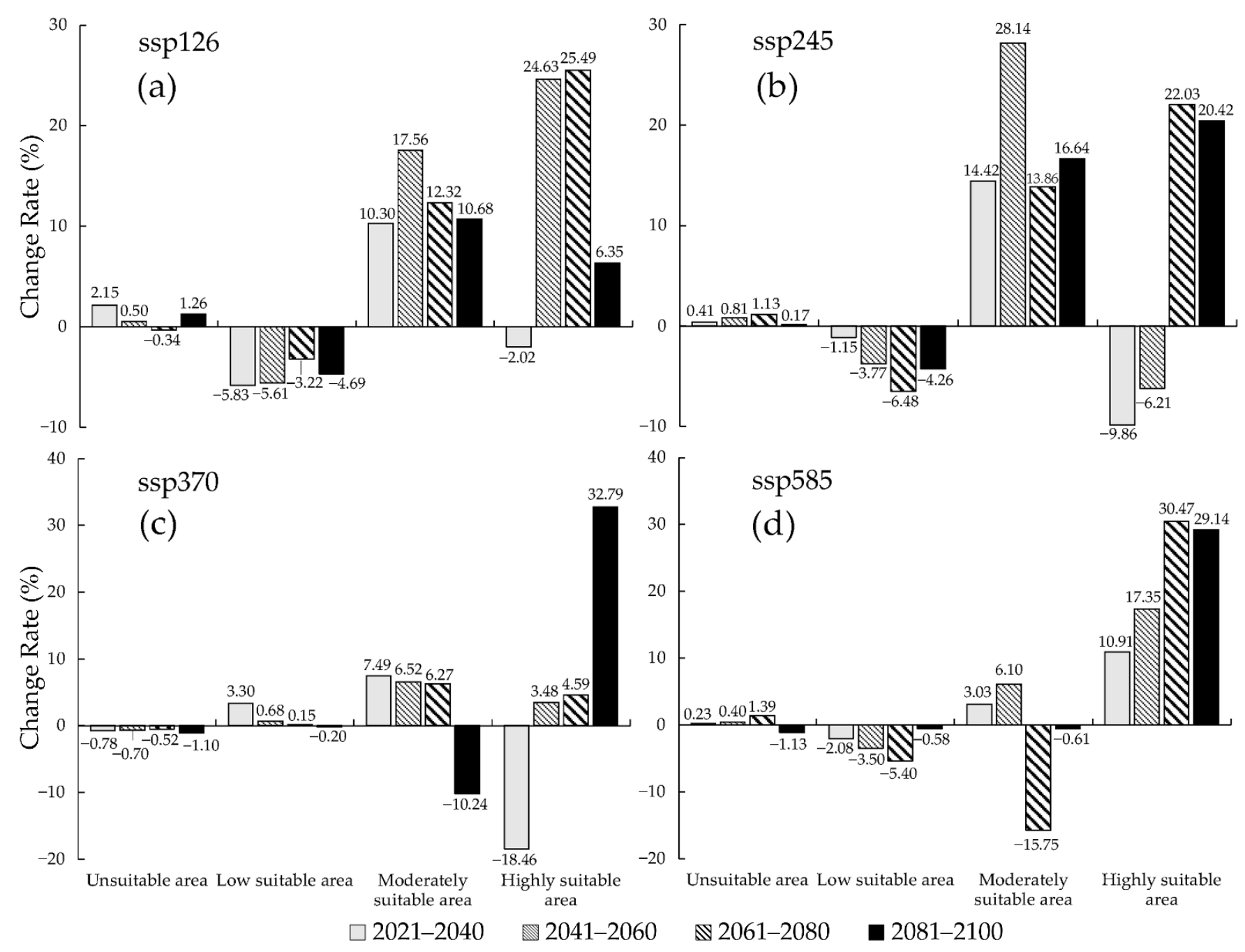

Figure 8. The change rate of predicted potential distribution of $S$. juvencus around the world under the future climate conditions during the periods of the 21st century under four CMIP6 climate scenarios, compared with the potential distribution area under near current climate conditions and four shared socio-economic pathways: (a) ssp126; (b) ssp245; (c) ssp370; (d) ssp585.

The increasing trend of highly suitable areas is evident under various future climate scenarios (Figure 8). Moderately suitable areas show an increasing trend under future climate scenarios 2081-2100 ssp126 and ssp245 (Figure 8a,b). The maximum observed increase in the predicted highly suitable area appears in the period 2081-2100 ssp370, reaching an area of $0.58 \times 10^{7} \mathrm{~km}^{2}$, with an increase of $32.79 \%$ compared to that under near current climate conditions (Figure 8c) and an increasing trend for the same period under ssp245 and ssp585 (Figure 8b,d). While the minimum suitability area was predicted for the period 2021-2040 ssp370, reaching an area of $0.35 \times 10^{7} \mathrm{~km}^{2}$, with a decrease of $18.46 \%$ compared to that under near current climate conditions (Figure 8c). Overall, the trends for low suitable areas are similar in different future climate conditions.

Compared to the near current climatic condition, the actual global distribution, as presented by occurrence points, of $S$. juvencus under the future climatic condition, has changed (Figure 9). The number of occurrence points of $S$. juvencus is predicted to increase by $2.59 \%$ in moderately suitable areas under the future climatic condition 2061-2080, and in highly suitable areas it increases by $0.37 \%$ under the future climatic condition 2081-2100 (Figure 9a). Curiously, the actual number of occurrence points in highly suitable areas shows a decrease under the various future climate scenarios (Figure $9 \mathrm{~b}-\mathrm{d}$ ). For the moderately suitable areas, there is a general increase in the number of occurrence points 
under the future climatic conditions, with the highest change recorded during the periods 2061-2080 ssp370 (Figure 9c) and 2061-2080 ssp585 (Figure 9d).

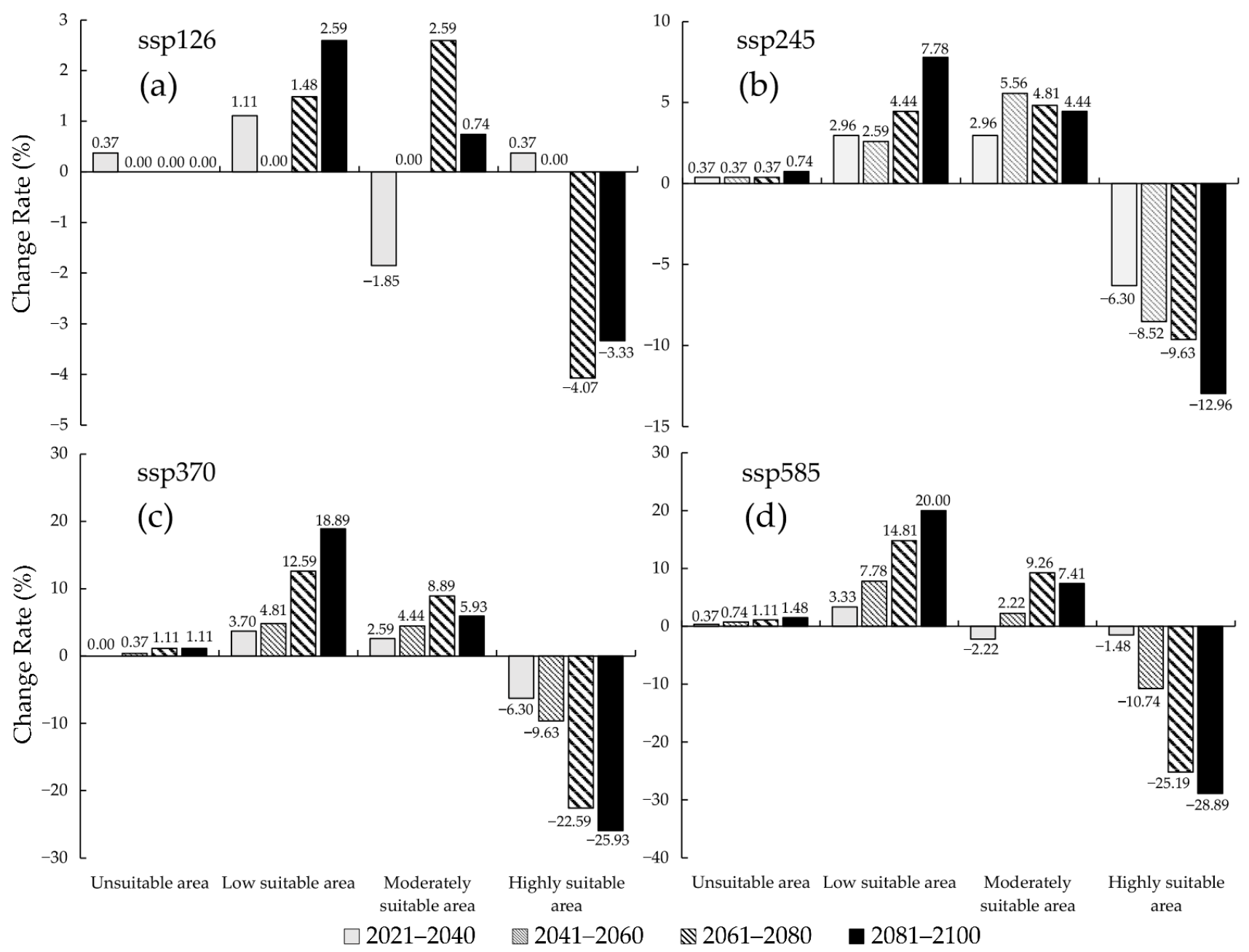

Figure 9. The change rate of predicted potential distribution of $S$. juvencus around the world under the future climate conditions during the periods of the 21st century under four CMIP6 climate scenarios, compared with the number of occurrence points under near current climate conditions and four shared socio-economic pathways: (a) ssp126; (b) ssp245; (c) ssp370; (d) ssp585.

\section{Discussion}

In this study, we found that the wood wasp, S. juvencus, possesses highly suitable areas in the Northern Hemisphere and can spread to previously unsuitable and moderately suitable areas under future climate scenarios in the 21st century. As an invasive alien species, S. juvencus has been introduced intentionally or unintentionally by humans to regions outside their autochthonous geographic distribution, including New Zealand and parts of North America [27,55-57]. Like all wood wasps, the species is easily moved in solid wood packing materials with or without bark used in trade; its larvae and pupae can be introduced and co-infest host plants along with other wood wasps. Given the species' adaptability to temperature and precipitation, suitable areas may experience severe infestation, leading to high economic losses, especially in the timber industry.

From 2016 to 2020, we have revisited some of the reported records of Chinese and European species, deleting and correcting old records and adding new ones. We further found that $S$. juvencus could be easily caught in traps for bark beetles and long-horned beetles, which seemed to be a common pattern of wood wasps associated with other wood borers. 


\subsection{The Association between Environmental Variables and the Potential Spread of S. juvencus}

We found that the worldwide distribution of $S$. juvencus is mainly impacted by monthly average maximum temperature in February (tmax2), which influenced the species' distribution and contributed unique information in predicting area suitability. The following were the maximum temperatures of the warmest month (bio5), monthly average minimum temperature in July (tmin7), and monthly total precipitation in June (prec6), suggesting strong environmental adaptability driven by temperature (tmax2, tmin7, bio5, and bio7) and precipitation (prec6, prec9, and bio14) (Figure 5).

In this study, the suitable distribution areas and unsuitable distribution areas were defined by the lowest presence threshold (LPT). The range of predicted suitable habitats for S. juvencus under near current climatic conditions was $80^{\circ} \mathrm{N}-60^{\circ} \mathrm{S}$ (Figure $3 \mathrm{~b}$ ). The predicted suitable habitats for S. noctilio were $30^{\circ}-60^{\circ} \mathrm{N}$ and $25^{\circ}-55^{\circ} \mathrm{S}$ [30]; thus, when compared to S. noctilio, S. juvencus seems to have a larger area of suitable habitats, especially in Europe. However, S. noctilio, as an invasive species native to Eurasia, has a wider spread around the world, while $S$. juvencus has widely been established in the Northern Hemisphere. It is worth noting that $S$. noctilio and S. juvencus have many overlapping suitable habitats, potentially co-infesting the hosts and bringing them into the interspecific competition.

We found that the highly suitable area for $S$. juvencus under the near current climate covers a total area of $4.56 \times 10^{7} \mathrm{~km}^{2}$, and is primarily driven by summer rainfall patterns, temperature, and winter temperature. These areas increase by a slight proportion when modeled in future climate scenarios. Changes in environmental factors, especially temperature and rainfall, can influence microclimates, such as air temperature, wind speed, relative humidity, solar radiation, and sky radiation. It further influences the habitability of areas for the species, which depends on species' thermal tolerances, desiccation resistance, and metabolic processes $[58,59]$. The increased impact of climate change, particularly changes in rainfall and temperature patterns, can influence the species' survival ability by impacting the reproductive output, larval survival, and survival of fungal obligate mutualism as in the case of S. noctilio [60]. In the lifecycle of S. juvencus, unfavorable temperatures can lead to poor survival of eggs and larvae. The eggs are usually overwintered, but some are hatched in late summer, and the larvae over winter in the first or second instar. The prepupal stage lasts 4 to 6 weeks and is followed by the pupal stage for 2 to 3 weeks. In North America, the emergence period of $S$. juvencus mainly occurs from late summer to late autumn [61], while in Europe, the peak emergence period of $S$. juvencus extends to summer [26]. In China, according to our investigation from 2015 to 2019, S. juvencus was collected on Picea obovate, P. schrenkiana, and P. crassifolia forests during the middle of July to early September. S. juvencus was found to co-infest the weakened or dying host plant species with other Sirex wood wasps, including S. ermak, S. dux, Urocerus gigas, and Xeris spectrum in China, which means the emergence periods of some wood wasps are overlapping. Being infested by several Sirex wood wasp species may accelerate tree death $[62,63]$.

Temperature and precipitation have been shown to affect larvae, pupae, and the emergence of $S$. juvencus [64]. Thus, precipitation (prec6) and temperature (bio5 and tmin7) may affect the critical period that pupae emerge, and we show in this study that temperature is the most influential predictor of current and future distributions of $S$. juvencus. The biological characteristics of $S$. noctilio were used to estimate $S$. juvencus egg and larval development. The estimates indicated that immature larval stages developed progressively slower at temperatures below $15{ }^{\circ} \mathrm{C}$ and reached a lower threshold at about $6{ }^{\circ} \mathrm{C}$ under natural conditions. Complete development depends on temperatures occurring within the range of $12.5-33.5^{\circ} \mathrm{C}$ [65], and very few $S$. juvencus emerged when the maximum daily temperature was lower than $20^{\circ} \mathrm{C}$. [61]. Besides, in China, according to our observation, S. juvencus mainly emerged from 12 am to $5 \mathrm{pm}$, which is the warmest period of the day. In the current study, the maximum monthly temperature in February (tmax2) and the maximum temperature in the warmest month (bio5) ranged between $3-20{ }^{\circ} \mathrm{C}$ and $3-36{ }^{\circ} \mathrm{C}$, respectively; while the temperature ( $\operatorname{tmin} 7)$ during the emergence period of $S$. juvencus was 
3-23 ${ }^{\circ} \mathrm{C}$. In addition, $S$. juvencus, like other wood wasps, also forms an obligate mutualism association with a wood-rotting fungus, $A$. areolatum, which assists the larvae of $S$. juvencus in digesting plant cellulose, hemicellulose, or wood fibers. The larvae lack essential enzymes required for the digestion of these substances. The fungus, supported by the mucus, enables this by breaking down the cellulose and lignin in the wood, enabling the larvae to consume it [66]. The growth conditions of the obligate mutualistic fungus of $S$. juvencus, A. areolatum, are also affected by temperature. The growth condition of A. areolatum is limited to $10-30^{\circ} \mathrm{C}$, which overlaps with that of Sirex species [67]. Furthermore, the fungus prefers to grow in wood with a lower moisture content $[68,69]$. For another Sirex wood wasp, S. nitobei, the precipitation (prec7 and prec12) and temperature (tmax2 and tmin7), related to the periods of the emergence, growth of larvae and its obligate mutualistic fungus, also significantly impact its distribution [29]. This supports the result that temperature and precipitation suitability is critical in explaining the current and future distribution patterns of $S$. juvencus.

In comparison to the lifestyle of $S$. noctilio, $S$. juvencus is less cold-tolerant and requires much lower rainfall. For both species, larvae are highly cold-tolerant, with $S$. noctilio larvae able to supercool to $-24.27 \pm 0.62{ }^{\circ} \mathrm{C}[70]$, much lower than the suitable temperature of the maximum monthly temperature in February (tmax2) for S. juvenctus larvae (Figure 6a), thus possibly explaining some of the observed differences in distribution patterns.

By comparing with these results of suitable temperature for larvae and emergence obtained from the biological study and the maximum entropy model, it is evident that the physiological tolerance of $S$. juvencus to temperature is stronger than previously shown [71]. The rainfall also influenced the current and future distribution, S. juvencus prefers low rainfall areas and low moisture content in the host plant. Evidence indicates that the species also infested weak and dying trees that have already been infested by other wood wasps, which supports this finding that $S$. juvencus preferred lower moisture than other wood wasps. Furthermore, this could explain the spread of $S$. juvencus into moderately suitable areas as predicted by a maximum entropy model, and not always into highly suitable areas that may favor more dominant and competitive wood wasp species such as S. noctilio, which may also have higher thermal tolerances to extreme environments in its highly suitable areas.

\subsection{The Main Factors Affecting the Predictive Accuracy of the Maximum Entropy Model}

We found the maximum entropy model to be highly effective and accurate in predicting the potentially suitable areas of $S$. juvencus. The model yielded a high AUC value, and low ORmtp and OR10 (Table 3) [50,54]. Besides, only a slight deviation between the mean omission curve on the test data and the predicted omission (Figure 2) indicated that the predicted result's accuracy is a high predictive ability. Using the AUC value to verify the maximum entropy model's predictive accuracy is controversial. Even though the AUC value as an evaluation criterion of the maximum entropy model is widely used, it does present some problems: (1) it ignores the predicted probability values and the goodness-of-fit of the model; (2) it summarizes the test performance over regions of the ROC space in which one would rarely operate; (3) it weights omission and commission errors equally; (4) it does not give information about the spatial distribution of model errors, and, most importantly, (5) the total extent to which models are carried out highly influences the rate of well-predicted absences and the AUC value [51]. The AUC value could vary with the selected background points' spatial range, with a more extensive spatial range resulting in a higher AUC value [52]. However, we did not find a significant difference between the AUC value and AUC ratios under different climate conditions in this study. The AUC values and AUC ratios were greater than 0.9 and 1.0, respectively, indicating that the predictive accuracy was a high predictive ability (Table 2). Moreover, it is important to incorporate up-to-date and relevant climate and environmental data when using distribution models. Here we used the updated WorldClim database with near current and future climate variables, which gave predictions that are much closer to 
reality and have biological relevance. However, there is still a 20-year gap with the current timeline, which means that there are still restrictions for predicting the potentially suitable area of the species as researchers cannot access the latest climate database.

\subsection{The Worldwide Suitable Area of S. juvencus under the Future Climate Conditions and the Suggestions about the Pest Control}

Comparing the range of the potentially suitable area of S. juvencus under the future climate conditions with that under the near current climate conditions, the area of the total suitable area was increasing under the four CMPI6 climate scenarios, with a slight increase of $0.37 \%$ in highly suitable areas under climate scenario 2021-2040 ssp126, an increase in land area from $9.03 \times 10^{7} \mathrm{~km}^{2}$ to $9.23 \times 10^{7} \mathrm{~km}^{2}$ of predicted potentially highly suitable areas. The percentage of increase in the area of the moderately suitable area was $9.26 \%$, and that of the low suitable area was $20.00 \%$, showing a more rapid increase in suitability under the scenarios 2061-2080 ssp585 and 2041-2060 ssp585; under the same climate scenarios, low suitable areas increased by $1.48 \%$. Overall, under the climate scenarios 2081-2100 ssp585 (highly suitable area), 2021-2040 ssp126 (moderately suitable area), and 2041-2060 ssp126 (low suitable area), there is a rapid decrease in the highly suitable area and a general decrease in the moderately and low suitable areas, which could be associated with rainfall patterns and temperature variations in these periods and climate scenarios that would affect the lifecycle of $S$. juvencus as well as its obligate mutualistic fungus. The most apparent changes in the suitable areas were in Europe, North America, and Southwest China. In Europe, the suitable area moved towards the north. The area of the highly suitable area increased in northwestern North America and Southwest China. By comparing the change rate of existence probability of the current occurrence points, we can also analyze which CMIP6 climate scenario is more reasonable under different future climate conditions. In the climate scenarios 2081-2100 ssp370 (highly suitable area), 2021-2040 ssp245 (moderately suitable area), 2021-2040 ssp370 (low suitable area), and 2021-2400 ssp126 (unsuitable area), the increases were $37.79 \%, 28.14 \%, 3.30 \%$, and $2.15 \%$, respectively. Furthermore, in the climate scenarios 2021-2040 ssp370 (highly suitable area), 2061-2080 ssp585 (moderately suitable area), 2061-2080 ssp245 (low suitable area), and 2021-2400 ssp126 (unsuitable area), the decreases were $18.46 \%, 15.75 \%, 6.48 \%$, and $1.13 \%$, respectively. The time interval of the 21st century periods under four CMIP6 climate scenarios is ten years, and thus within ten years, the area of the suitable area would not change significantly. As a result, the potentially suitable area obtained under the scenario ssp126 might be a more realistic result.

The spread of $S$. juvencus could change with the climate change patterns associated with low rainfall and high temperatures. S. juvencus are highly adaptable and can spread quickly due to their distance dispersal abilities. S. juvencus showed high adaptability levels and are likely to have physiological tolerance to highly variable environmental conditions. The dependency of $S$. juvencus on its obligate mutualistic fungus can influence the potential survival in new areas. Since evidence suggests some dependencies on other Sirex species for host infestation, generalized pest control could also affect $S$. juvencus.

\section{Conclusions}

We found that the maximum entropy model is effective in predicting the potential global distribution of $S$. juvencus by predicting potential future climatic conditions relative to current distribution patterns. We have incorporated near current and future climate scenarios allowed for a better predictive outcome and enabled the precise identification of important environmental variables driving current and potential future suitable areas, which were mostly driven by temperature and precipitation. As expected, temperature and precipitation were very important in predicting the potentially suitable areas of $S$. juvencus, which could be related to the biological requirements for its whole life cycle and obligate mutualistic fungus. Under future climate conditions, the total area and the area of suitable areas for $S$. juvencus will increase as the species moves more into moderately suitable areas. The results indicate that the movement of the species into moderately suitable areas could be due to competition or dependency on co-infestation with other species or the limitation 
of rainfall. The area with moderate suitability could have much lower rainfall and could also be the site of abundant other Sirex wood wasp species that $S$. juvencus can co-infest the host plants with.

Author Contributions: Conceptualization, T.G. and J.S.; Methodology, T.G.; Software, T.G.; Data collection, T.G.; Writing—original draft preparation, T.G.; Writing—review and editing, J.S.; Supervision, J.S.; Project administration, J.S.; Funding acquisition, J.S. All authors have read and agreed to the published version of the manuscript.

Funding: This research was supported by General Program of National Natural Science Foundation of China (31770687), Forestry Science and Technology Innovation Project of Jiangxi Provincial Department of Forestry (2019HXFWLXY048), and Short-term International Student Program for Postgraduates of Forestry First-Class Discipline (2019XKJS0501).

Acknowledgments: We acknowledge the groups of ArcGIS, MaxEnt, and WorldClim for their contribution in making this simulation possible. The authors would like to thank TopEdit (www. topeditsci.com (accessed on 4 March 2021)) for its linguistic assistance during the preparation of this manuscript. We thank Roques, Auger-Rozenberg, Urvois, and Bernard of Unité de Recherche de Zoologie Forestière, INRAE Orléans, for providing the S. juvencus specimens. And we also thank Goulet of Horticultural Research and Development Center, Agri-Food Canada, for recognizing S. juvencus specimens. Last but not least, we would like to thank anonymous reviewers for valuable comments that helped us improve the quality of this article.

Conflicts of Interest: The authors declare no conflict of interest.

\section{References}

1. Andersson, H. Bidrag till kännedomen om de skandinaviska växtsteklarnas utbredning (Hym. Phytophaga). Opusc. Entomol. 1962, 27, 28-34.

2. Chevin, H.; Tiberghien, G. Les collections entomologiques de la faculté des sciences de Rennes-Beaulieu. Catalogue raisonné et commenté. IV Fonds, E. Hervé: 1, Hymenoptera Symphyta. Bull. Soc. Sci. Nat. Ouest Fr. 1998, 20, 129-140.

3. Chevin, H.; Chevin, S.; De Flaugergues, F.; Moussa, A. Inventaire des Hyménoptères Symphytes du département de l'Isère. Publ. Soc. Linn. Lyon 1995, 64, 254-258. [CrossRef]

4. Chevin, H.; Ellis, W.N.; Schneider, N. Mise à jour du répertoire des hyménoptères symphytes du Luxembourg (Insecta, Hymenoptera, Symphyta). Bull. Soci. Nat. Luxemb. 2011, 112, 109-117.

5. Lacourt, J. Désignation de lectotypes pour cinq espèces de Symphytes décrites de Grèce par Brullé en 1832. [Hymenoptera]. Rev. Fr. Entomol. 1979. 2001, 23, 169-170.

6. Landin, B.O. Fältfauna-Insekter. Nat. Kult. Stockh. 1967, 2, 381-1053.

7. Liston, A.D. Compendium of European Sawflies; List of species, modern nomenclature, distribution, foodplants, identification literature; Chalastos Forestry: Gottfrieding, Germany, 1995; pp. 1-190.

8. Nuorteva, M.; Nuorteva, J.; Olsen, T.J. Records of sawflies (Hymenoptera: Symphyta) from Østfold, Southern Norway. Sahlbergia 2005, 10, 68-79.

9. Zhelochovtsev, A.N.; Prochorova, L.G. Pililschtschiki i rogochvosty moskovskoj oblasti. Sb. Tr. Zool. Muz. MGU 1976, 15, 97-110.

10. Wei, M.C.; Nie, H.Y.; Taeger, A. Sawflies (Hymenoptera: Symphyta) of China-Checklist and Review of Research; Recent Sawfly Research: Synthesis and Prospects; Verlag Goecke \& Evers: Keltern, Germany, 2006; pp. 505-574.

11. Titovšek, J. Pršice in žuželke-moteči dejavniki na gozdnem drevju v Sloveniji. Zb. Gozd. Lesar. 1993, 42, 67-84.

12. Schwarz, M. Siricidae (Holzwespen), Xiphydriidae (Schwertwespen) und Orussidae (Hymenoptera, Symphyta) Oberösterreichs (Österreich). Beitr. Naturk. Oberöstereichs 1998, 6, 325-336.

13. Schirmer, C. Verzeichnis der in der Umgebung Berlins beobachteten Tenthrediniden (Blatt-und Holzwespen). Allg. Z. Entomol. Neudamm. 1901, 6, 279-282.

14. Schedl, W. Neunachweise und derzeitiger Faunenbestand von Pflanzenwespen der Kanarischen Inseln II (Insecta: Hymenoptera: Symphyta); Linzer Biologische Beiträge: Linz, Austria, 2009; pp. 753-757.

15. Saini, M.S.; Blank, S.M.; Smith, D.R. Checklist of the Sawflies (Hymenoptera: Symphyta) of India. Recent Sawfly Research: Synthesis and Prospects; Verlag Goecke \& Evers: Keltern, Germany, 2006; pp. 575-612.

16. Roller, L. Check-list of the sawflies (Hymenoptera, Symphyta) of Slovakia. Entomol. Probl. 1999, 30, 37-48.

17. Pesarini, F. Imenotteri Sinfiti raccolti in Sardegna e conservati nelle collezioni dell'Istituto di Entomologia Agraria dell'Universita di Sassari (Hymenoptera Symphyta). Ann. Mus. Civ. Stor. Nat. 2001, 4, 117-129.

18. Perović, F.; Leiner, S. Index of the sawflies sensu lato (Hymenoptera, Symphyta) of Croatia. Nat. Croat. 1996, 5, $359-381$.

19. Xiao, G.R.; Huang, X.Y.; Zhou, S.Z.; Wu, J.; Zhang, P. Siricidae; Economic Sawfly Fauna of China (Hymenoptera, Symphyta); Tianze Eldonejo: Xi'an, China, 1991; pp. 37-42. 
20. Spradbery, J.P.; Kirk, A.A. Aspects of the ecology of siricid woodwasps (Hymenoptera: Siricidae) in Europe, North Africa and Turkey with special reference to the biological control of Sirex noctilio F. in Australia. Bull. Entomol. Res. 1978, 68, 341-359. [CrossRef]

21. Gaut, I.P. Identity of the fungal symbiont of Sirex noctilio. Aust. J. Biol. Sci. 1969, 22, 905-914. [CrossRef]

22. Morgan, F.D. Bionomics of siricidae. Annu. Rev. Entomol. 1968, 13, 239-256. [CrossRef]

23. Stillwell, M.A. Decay Associated with Woodwasps in Balsam Fir Weakened by Insect Attack. For. Sci. 1960, 6, $225-231$.

24. Coutts, M.P. The mechanism of pathogenicity of Sirex noctilio on Pinus radiata II. Effects of S. noctilio mucus. Aust. J. Biol. Sci. 1969, 22, 1153-1162. [CrossRef]

25. Stillwell, M.A.; Kelly, D.J. Fungous deterioration of balsam fir killed by spruce budworm in northwestern New Brunswick. For. Chron. 1964, 40, 482-487. [CrossRef]

26. Spradbery, J.P.; Kirk, A.A. Experimental studies on the responses of European siricid woodwasps to host trees. Ann. Appl. Biol. 1981, 98, 179-185. [CrossRef]

27. Mack, R.; Smith, M. Invasive plants as catalysts for the spread of human parasites. NeoBiota 2011, 9, 13-29. [CrossRef]

28. Early, R.; Bradley, B.A.; Dukes, J.S.; Lawler, J.J.; Olden, J.D.; Blumenthal, D.M.; Gonzalez, P.; Grosholz, E.D.; Ibañez, I.; Miller, L.P.; et al. Global threats from invasive alien species in the twenty-first century and national response capacities. Nat. Commun. 2016, 7, 1-9. [CrossRef] [PubMed]

29. Gao, T.; Xu, Q.; Liu, Y.; Zhao, J.; Shi, J. Predicting the Potential Geographic Distribution of Sirex nitobei in China under Climate Change Using Maximum Entropy Model. Forests 2021, 12, 151. [CrossRef]

30. Phillips, S.J.; Anderson, R.P.; Schapire, R.E. Maximum entropy modeling of species geographic distributions. Ecol. Model. 2006, 190, 231-259. [CrossRef]

31. Phillips, S.J.; Dudík, M. Modeling of species distributions with Maxent: New extensions and a comprehensive evaluation. Ecography 2008, 31, 161-175. [CrossRef]

32. Merow, C.; Smith, M.J.; Silander, J.A., Jr. A practical guide to MaxEnt for modeling species' distributions: What it does, and why inputs and settings matter. Ecography 2013, 36, 1058-1069. [CrossRef]

33. Phillips, S.J.; Anderson, R.P.; Dudík, M.; Schapire, R.E.; Blair, M.E. Opening the black box: An open-source release of Maxent. Ecography 2017, 40, 887-893. [CrossRef]

34. Liu, Y.; Shi, J. Predicting the Potential Global Geographical Distribution of Two Icerya Species under Climate Change. Forests 2020, 11, 684. [CrossRef]

35. Fan, S.; Chen, C.; Zhao, Q.; Wei, J.; Zhang, H. Identifying Potentially Climatic Suitability Areas for Arma custos (Hemiptera: Pentatomidae) in China under Climate Change. Insects 2020, 11, 674. [CrossRef]

36. Wan, J.; Wang, R.; Ren, Y.; McKirdy, S. Potential Distribution and the Risks of Bactericera cockerelli and Its Associated Plant Pathogen Candidatus Liberibacter Solanacearum for Global Potato Production. Insects 2020, 11, 298. [CrossRef]

37. Tiffin, H.S.; Peper, S.T.; Wilson-Fallon, A.N.; Haydett, K.M.; Cao, G.; Presley, S.M. The Influence of New Surveillance Data on Predictive Species Distribution Modeling of Aedes aegypti and Aedes albopictus in the United States. Insects 2019, 10, 400. [CrossRef]

38. Elith, J.; Phillips, S.J.; Hastie, T.; Dudík, M.; Chee, Y.E.; Yates, C.J. A statistical explanation of MaxEnt for ecologists. Divers. Distrib. 2011, 17, 43-57. [CrossRef]

39. Guevara, L.; Gerstner, B.E.; Kass, J.M.; Anderson, R.P. Toward ecologically realistic predictions of species distributions: A cross-time example from tropical montane cloud forests. Glob. Chang. Biol. 2018, 24, 1511-1522. [CrossRef] [PubMed]

40. Hortal, J.; Roura-Pascual, N.; Sanders, N.J.; Rahbek, C. Understanding (insect) species distributions across spatial scales. Ecography 2010, 33, 51-53. [CrossRef]

41. Sillero, N. What does ecological modelling model? A proposed classification of ecological niche models based on their underlying methods. Ecol. Model. 2011, 222, 1343-1346. [CrossRef]

42. Anderson, R.P.; Gonzalez, I., Jr. Species-specific tuning increases robustness to sampling bias in models of species distributions: An implementation with Maxent. Ecol. Model. 2011, 222, 2796-2811. [CrossRef]

43. Verbruggen, H.; Tyberghein, L.; Belton, G.S.; Mineur, F.; Jueterbock, A.; Hoarau, G.; Gurgel, C.F.D.; De Clerck, O. Improving transferability of introduced species' distribution models: New tools to forecast the spread of a highly invasive seaweed. PLoS ONE 2013, 8, e68337. [CrossRef]

44. Phillips, S.J.; Dudík, M.; Schapire, R.E. A maximum entropy approach to species distribution modeling. In Proceedings of the Twenty-First International Conference on Machine Learning, Banff, AB, Canada, 4-8 July 2004; Association for Computing Machinery: New York, NY, USA, 2004; pp. 655-662.

45. Akaike, H. Information theory and an extension of the maximum likelihood principle. In Proceedings of the Second International Symposium on Information Theory, Tsahkadsor, Armenia, 2-8 September 1971; Akadémiai Kiadó: Budapest, Hungary, 1973; pp. 267-281.

46. Morales, N.S.; Fernández, I.C.; Baca-González, V. MaxEnt's parameter configuration and small samples: Are we paying attention to recommendations? A systematic review. Peer] 2017, 5, e3093. [CrossRef] [PubMed]

47. Radosavljevic, A.; Anderson, R.P. Making better Maxent models of species distributions: Complexity, over fitting and evaluation. J. Biogeogr. 2014, 4, 629-643. [CrossRef]

48. Lu, Z. Prediction of potential distribution area of Euphorbia dentata in China based on MAXENT model. J. Biosaf. 2015, 24, 194-200. 
49. Pearson, R.G.; Raxworthy, C.J.; Nakamura, M.; Peterson, A.T. Predicting species distributions from small numbers of occurrence records: A test case using cryptic geckos in Madagascar. J. Biogeogr. 2007, 34, 102-117. [CrossRef]

50. Swets, J.A. Measuring the accuracy of diagnostic systems. Science 1988, 240, 1285-1293. [CrossRef] [PubMed]

51. Lobo, J.M.; Jiménez-Valverde, A.; Real, R. AUC: A misleading measure of the performance of predictive distribution models. Glob. Ecol. Biogeogr. 2008, 17, 145-151. [CrossRef]

52. Peterson, A.T.; Papeş, M.; Soberón, J. Rethinking receiver operating characteristic analysis applications in ecological niche modeling. Ecol. Model. 2008, 213, 63-72. [CrossRef]

53. Qiao, H.J.; Peterson, A.T.; Campbell, L.P.; Soberón, J.; Ji, L.Q.; Escobar, L.E. NicheA: Creating virtual species and ecological niches in multivariate environmental scenarios. Ecography 2016, 39, 805-813. [CrossRef]

54. Shcheglovitova, M.; Anderson, R.P. Estimating optimal complexity for ecological niche models: A jackknife approach for species with small sample sizes. Ecol. Model. 2013, 269, 9-17. [CrossRef]

55. Miller, D.; Clark, A.F. Sirex noctilio (Hym.) and its Parasite in New Zealand. Bull. Entomol. Res. 1935, 26, 149-154. [CrossRef]

56. Burnip, G.M.; Voice, D.; Brockerhoff, E.G. Interceptions and incursions of exotic Sirex species and other siricids (Hymenoptera: Siricidae). N. Z. J. For. Sci. 2010, 40, 133-140.

57. Schiff, N.M.; Goulet, H.; Smith, D.R.; Boudreault, C.; Wilson, A.D.; Scheffler, B.E. Siricidae (Hymenoptera: Symphyta: Siricoidea) of the western hemisphere. Can. J. Arthropod Identif. 2012, 21, 1-305.

58. Kearney, M.R.; Isaac, A.P.; Porter, W.P. microclim: Global estimates of hourly microclimate based on long-term monthly climate averages. Sci. Data 2014, 1, 1-9. [CrossRef]

59. Schouten, R.; Vesk, P.A.; Kearney, M.R. Integrating dynamic plant growth models and microclimates for species distribution modelling. Ecol. Model. 2020, 435, 109262. [CrossRef]

60. Talbot, P.H.B. The Sirex-Amylostereum-Pinus association. Annu. Rev. Phytopathol. 1977, 15, 41-54. [CrossRef]

61. Stillwell, M.A. Woodwasps (Siricidae) in conifers and the associated fungus, Stereum chailletii, in eastern Canada. For. Sci. 1966, $12,121-128$.

62. Wang, M.; Bao, M.; Ao, T.G.; Ren, L.L.; Luo, Y.Q. Population distribution patterns and ecological niches of two Sirex species damaging Pinus sylvestris var. mongolica. Chin. J. Appl. Entomol. 2017, 54, 924-932.

63. Kobayashi, T.; Sasaki, K.; Enda, N. Correlation between Sirex nitobei and Amylostereum areolatum, associated with the death of Japanese pine trees during winter season. J. Jpn. For. Soc. 1978, 60, 405-411.

64. Spradbery, J.P. A comparative study of the phytotoxic effects of siricid woodwasps on conifers. Ann. Appl. Biol. 1973, 75, 309-320. [CrossRef]

65. Madden, J.L. Egg and larval development in the woodwasp, Sirex noctilio F. Aust. J. Zool. 1981, 29, 493-506. [CrossRef]

66. Cartwright, K.S.G. A further note on fungus association in the Siricidae. Ann. Appl. Biol. 1938, 25, 430-432. [CrossRef]

67. Vanbergen, A.J.; Espíndola, A.; Aizen, M.A. Risks to pollinators and pollination from invasive alien species. Nat. Ecol. Evol. 2018, 2, 16-25. [CrossRef]

68. Coutts, M.P.; Dolezal, J.E. Sirex noctilio, its associated fungus, and some aspects of wood moisture content. Aust. For. Res. 1965, 1, $3-13$.

69. Coutts, M.P. The mechanism of pathogenicity of Sirex noctilio on Pinus radiata I. Effects of the symbiotic fungus Amylostereum sp. (Thelophoraceae). Aust. J. Biol. Sci. 1969, 22, 915-924. [CrossRef]

70. Li, C.C.; Wang, L.X.; Ren, L.L.; Li, H.D.; Luo, Y.Q. Effects of Temperature Adaptation of Symbiotic Wood-decay Fungus Amylostereum areolatum on Potential Distribution Area of Sirex noctilio. J. Northeast. For. Univ. 2019, 47, $112-117$.

71. Sun, X.T.; Xu, Q.; Luo, Y.Q. A Maximum Entropy Model Predicts the Potential Geographic Distribution of Sirex noctilio. Forests 2020, 11, 175. [CrossRef] 